\title{
HAMBATAN INTEGRASI IDENTITAS MUSLIM DI BARAT: PENELUSURAN KONSEP HUMANISME, PERANG SALIB, DAN TANTANGAN MASA DEPAN
}

\author{
Wirawan Sukarwo \\ Program Studi Desain Komunikasi Visual, \\ Universitas Indraprasta PGRI Jakarta
}

\begin{abstract}
Abstrak. Sejak peradaban Barat menjadikan humanisme sebagai acuan tata nilai dalam membentuk kehidupan bermasyarakat mereka, terjadi banyak konfrontasi dengan komunitas Islam. Humanisme yang kemudian melahirkan perlindungan terhadap kebebasan berekspresi sering kali masuk ke wilayah penistaan nilai keagamaan (blasphemy). Artikel ini mencoba menelusuri titik tengkar yang melahirkan hambatan integrasi identitas muslim di Barat. Riset yang dilakukan berjenis kualitatif deskriptif dengan metode penelusuran literatur. Perbandingan humanisme Barat dan Islam dalam artikel ini dilakukan dengan menggunakan studi komparasi yang digagas Ali Syariati. Berdasarkan hasil penelusuran, terdapat perbedaan mendasar yang sulit dikompromikan antara humanisme Barat dan Islam, serta trauma Perang Salib yang masih terasa. Hal tersebut perlu dipahami dengan baik agar bisa memunculkan kesadaran untuk menekan intensitas konflik antara masyarakat Barat dengan komunitas muslim di wilayah mereka.
\end{abstract}

Kata kunci: Ali Syariati, Barat, humanisme, identitas, Islam

\begin{abstract}
Since Western civilization has made humanism a reference for values in shaping their social life, there have been many confrontations with the Islamic community. Humanism, which then gave birth to the protection of freedom of expression, often entered the area of blasphemy. This article tries to explore the points of conflict that have created barriers to the integration of Muslim identity in the West. The research was conducted in a descriptive qualitative type with the literature study method. The comparison of Western humanism and Islam in this article was carried out using a comparative study initiated by Ali Syariati. Based on the results of the research, there were fundamental differences that were difficult to compromise between Western humanism and Islam, as well as the trauma of the Crusades that were still being around. This needs to be well understood in order to raise awareness to reduce the intensity of conflict between Western societies and Muslim communities in their region.
\end{abstract}

Keywords: Ali Syariati, the West, humanism, identity, Islam

Correspondence author: Wirawan Sukarwo, wirawansukarwo@gmail.com, Jakarta, Indonesia 


\section{PENDAHULUAN}

Belum lama ini publik dunia dihebohkan dengan pidato Presiden Perancis, Emanuel Macron yang menyebut Islam sebagai agama yang sedang mengalami krisis di tingkat global. Pidato itu merupakan bentuk pembelaan pemerintah Perancis terhadap kebebasan berekspresi di negara mereka yang dalam perspektif Macron sedang mengalami ancaman. Sontak masyarakat muslim di banyak negara di dunia bereaksi keras terhadap pernyataan tersebut dan menganggap pidato Macron sebagai penghinaan terhadap Islam.

Pidato kontroversial tersebut sebenarnya diawali dari serentetan peristiwa yang dimulai sejak tahun 2015 ketika sebuah majalah di Perancis, Charlie Hebdo menerbitkan kartun yang dianggap menghina Nabi Muhammad Saw. Pada tahun yang sama, kantor redaksi Charlie Hebdo mendapatkan serangan dari sekelompok orang yang merasa tersinggung dengan penerbitan kartun bergambar Nabi Muhammad Saw. Dalam aksi serangan tersebut, pemimpin redaksi Charlie Hebdo beserta beberapa orang karyawan tewas terbunuh. Peristiwa ini memunculkan ketegangan antara masyarakat Perancis yang mayoritas non-muslim dengan sesama warga negara mereka yang beragama Islam. Di tingkat global, saat itu muncul tagar yang mendunia yaitu \#JeSuisCharlie yang artinya aku adalah Charlie sebagai bentuk solidaritas terhadap Charlie Hebdo.

Peristiwa tahun 2015 tersebut teramplifikasi kembali pada tahun 2020 ketika seorang guru sejarah bernama Samuel Paty tewas dibunuh oleh seorang muslim warga negara Perancis keturunan Chechnya. Pembunuhan tersebut diawali oleh viralnya video keluhan orang tua salah satu murid Paty yang keberatan saat sang guru menampilkan kartun Charlie Hebdo edisi Nabi Muhammad Saw sebagai contoh dari kebebasan berekspresi. Video keluhan yang viral itu mendapatkan reaksi yang hebat di tengah-tengah komunitas muslim Perancis hingga akhirnya berujung pada peristiwa pembunuhan Samuel Paty.

Publik Perancis yang diwakili oleh Presiden Emanuel Macron bereaksi keras terhadap peristiwa tersebut melalui pidato yang isinya dianggap melecehkan dan menghina ajaran Islam. Melalui tagar \#BoycottFranceProduct atau \#ShameOnYouMacron komunitas muslim di seluruh dunia menunjukkan protes mereka. Lebih jauh, otoritas Perancis mulai merancang produk undang-undang yang nantinya akan membatasi kegiatan dakwah keislaman di Perancis sebagai wujud kesetiaan mereka pada nilai-nilai sekular di negara tersebut.

Situasi semacam itu membuat kondisi umat Islam di Perancis semakin sulit mengintegrasikan identitas mereka yang selama ini memang sudah bermasalah. Tidak hanya itu, beberapa hak mendasar yang selama ini diberikan terkait aktivitas peribadatan dan pembangunan tempat ibadah terancam sepenuhnya dilarang. Pemerintah Perancis bahkan mencabut izin banyak lembaga filantropi yang berafiliasi pada komunitas muslim di Perancis. Hal tersebut merupakan ekses dari usaha pemurnian sekularisme yang dianggap sakral bagi Perancis.

Kondisi di Perancis adalah salah satu bentuk sulitnya proses integrasi identitas muslim di Barat. Berbagai wujud hambatan integrasi identitas muslim di negara Barat lainnya bisa ditelusuri dari catatan yang dibuat oleh Ahmed Labor tahun 1996 dalam bukunya yang berjudul A Heart Turned East. Buku tersebut diterjemahkan dalam Bahasa Indonesia dengan judul Pergulatan Muslim di Barat. Labor memaparkan kondisi yang 
memprihatinkan terkait sulitnya seorang muslim mendapatkan pengakuan kesetaraan sebagai warga negara di negara-negara Barat. Terdapat semacam kecurigaan terhadap komunitas muslim yang dianggap memiliki potensi untuk menghancurkan tata nilai humanisme di Barat. Ditambah lagi dengan trauma sejarah Perang Salib yang seringkali ditulis secara tidak berimbang. Dan yang terakhir adalah fenomena terorisme Internasional yang distigmatisasi secara keliru sebagai bagian dari ajaran Islam mengenai jihad. Ketiga hal tersebut menciptakan hambatan dalam proses integrasi yang seharusnya mulus ketika seorang muslim menjadi warga di salah satu negara Barat.

Hambatan integrasi komunitas muslim di Perancis sendiri memang tidak sepenuhnya mewakili kondisi yang terjadi di negara-negara Barat lainnya. Meski demikian, konsep humanisme yang diadopsi Perancis sejak revolusi 1789 merupakan core value dari tatanan humanisme yang menjadi gejala umum perkembangan peradaban Barat hingga hari ini. Yang membedakan hanyalah intensitas dan kontraksi konflik yang terjadi. Pada kasus Perancis, intensitas konflik menjadi cukup tinggi dan sampai pada titik meresahkan ketika sebuah aksi hampir selalu berbalas reaksi dan begitu seterusnya.

Artikel ini memaparkan fenomena problematika integritas keislaman dari sudut pandang seorang sosiolog Iran bernama Ali Syariati yang pernah mengulas perbedaan konsep humanisme Barat dan Islam. Ali Syariati sendiri merupakan seorang intelektual revolusionis Iran yang menempuh studi sosiologi di Perancis. Ia menjadi salah satu tipe ideal cendikiawan muslim modern yang juga dianggap sebagai sosok penting dalam kebangkitan kelompok intelektual Islam, termasuk di Indonesia (Mujiburrahman, 2018: 287). Dalam pandangan Ali Syariati, terdapat perbedaan mendasar terkait akar humanisme Barat dengan Islam yang ternyata sulit dikompromikan. Meski demikian, pemahaman terkait perbedaan konsep humanisme tersebut seharusnya menjadi sebuah kesadaran bagi seluruh masyarakat di Barat untuk membela koeksistensi semua golongan. Ali Syariati juga menyampaikan kritik terhadap kondisi umat Islam yang begitu tertinggal dari peradaban Barat dalam hal penguasaan sains dan teknologi. Sebaliknya, ia juga mengkritik Barat yang dianggap terlalu sering menciptakan tragedi kemanusiaan yang ironisnya dilatari oleh filsafat humanisme ateistik.

\section{HASIL DAN PEMBAHASAN}

\section{Humanisme Barat Versus Islam}

Jika merujuk pada pemikiran Ali Syariati, maka perbedaan konsep dasar humanisme antara Barat dan Islam memang sulit untuk dikompromikan. Menurut Syariati, konsep Humanisme yang berkembang di Barat memang memiliki akar genealogis dari era pemikiran Helenisme (Yunani kuno) dengan mitologi Yunani yang menjadi semacam panduan hidup bagi segenap masyarakatnya. Syariati mengutip cerita mengenai Prometheus dalam mitologi Yunani sebagai contoh penjelasan. Dikisahkan dalam mitologi Yunani tentang perjuangan seorang Dewa dari golongan Titan bernama Prometheus yang berhasil menyelinap ke gunung Olympus lalu mencuri api dewa dan menyerahkannya pada umat manusia. Sebelumnya, Prometheus adalah dewa yang mengajarkan manusia banyak ilmu pengetahuan dan juga kesenian. Ia juga yang selalu berpihak pada kepentingan manusia tatkala ada ritual persembahan untuk 
para dewa yang ia anggap memberatkan manusia. Ia juga pernah membantu manusia untuk menipu Dewa dengan persembahan yang sudah dimodifikasi sehingga para dewa kesal.

Akibat tindakannya yang begitu provokatif, Prometheus dianggap musuh oleh Zeus, pemimpin tertinggi para Dewa di gunung Olympus. Zeus menghukum Prometheus dengan cara mengikatnya di sebuah batu untuk selamanya lalu mengirimkan burung elang setiap harinya untuk memakan hatinya (secara harfiah: liver) yang terus tumbuh. Meski dianggap bersalah dan dihukum oleh Zeus, sebaliknya Prometheus justru dianggap sebagai pahlawan di kalangan umat manusia. Ia dianggap sebagai sosok yang teguh membela kepentingan manusia dan berpihak pada manusia di hadapan arogansi para dewa. Di dalam mitologi Yunani juga dituliskan bahwa alasan utama Prometheus mencuri api dewa itu ialah karena ia merasa Zeus telah berbuat zalim terhadap umat manusia.

Ali Syariati mengajak para pembaca kisah ini untuk melihat konstruksi berpikir masyarakat Barat mengenai konsep ketuhanan berikut hubungan antara para dewa dan manusia. Dalam pandangan Ali Syariati, model persaingan, konflik, dan permusuhan antara manusia dengan dewa itu sudah menjadi semacam ide konseptual dalam alam pikir masyarakat Barat. Jadi, sekalipun pada perkembangannya di kemudian hari Barat bertransformasi menjadi penganut Kristen, paradigma permusuhan terhadap para dewa itu tetap ada di dalam benak mereka. Ketika Barat bertransformasi menjadi Kristen, kekuatan gereja kemudian mengambil alih dan menjadi determinan di era setelahnya di tengah masyarakat mereka. Namun, spirit perlawanan terhadap kekuasaan "langit" itu muncul kembali dan menempatkan struktur kekuasaan gereja layaknya para dewa Olympus. Di tengah otoritarianisme politik gereja di abad pertengahan dan mandeknya sains yang dikekang oleh dalil keagamaan inilah kemudian humanisme lahir sebagai bentuk filsafat pembebasan.

Filsafat humanisme sendiri lahir dalam spirit yang kurang lebih serupa dengan persaingan antara manusia dan para dewa di era mitologi Yunani. Meski yang dihadapi bukan lagi Zeus, tetapi semangat dasar untuk membebaskan manusia dari kekuatan supranatural tetap sama kadar dan intensitasnya. Pada intinya, aliran pemikiran ini membuang jauh peran dan otoritas keagamaan dalam membangun peradaban manusia seraya mendudukkan manusia sebagai subjek dan bukan lagi objek. Humanisme menggeser konsep teosentrisme yang sebelumnya dipegang menjadi antroposentrisme.

Sementara itu, Ali Syariati memberi catatan mengenai kedudukan manusia dan kemanusiaan dalam pandangan Islam yang bersifat diametral dengan konsepsi humanisme Barat. Sikap permusuhan antara kholiq (pencipta) dan makhluq (manusia) seperti yang ada dalam peradaban Barat tidak ditemukan dalam khasanah pemikiran Islam. Syariati memulai penjelasannya melalui dialektika kisah penciptaan Adam AS yang termaktub di dalam al-Quran. Mengacu pada ayat-ayat mengenai penciptaan manusia itulah Ali Syariati berpendapat bahwa di dalam Islam, kedudukan manusia sudah ditinggikan dan begitu diakui secara otentik di antara makhluk-makhluk ciptaan Tuhan lainnya.

Terdapat poin penting dalam konsep penciptaan manusia versi Islam menurut catatan Ali Syariati yaitu "kebebasan". Manusia diciptakan dengan kebebasan yang tidak perlu diperjuangkan seolah hal tersebut tidak serta merta ada dalam diri tiap manusia. Manusia diberi kebebasan sepenuhnya untuk menjalani kehidupan yang mereka inginkan dengan kesadaran penuh terhadap tanggung jawab dan konsekuensi 
atas pilihan hidupnya tersebut. Agama memberikan petunjuk untuk hidup yang ideal dan jalan kembali (afterlife) yang indah, tetapi pilihan sepenuhnya ada pada diri tiap manusia.

Mengenai tradisi permusuhan antara dunia bawah dengan dunia atas seperti yang diwariskan oleh mitologi Yunani, hal tersebut tidak terdapat dalam Islam. Bagi Ali Syariati, model pemisahan dan dualisme semacam itu hanya ada dalam ajaran-ajaran syirik yang kontras dengan tauhid. Dalam ajaran tauhid, manusia dan alam merupakan satu kesatuan yang eksis yang memiliki makna, tujuan, serta kesadaran diri (Syariati, 1984).

"Kontradiksi antara alam dan meta alam, antara materi dan arti, antara dunia sekarang dan akhirat, antara yang indrawi dan yang supra indriawi, antara roh dan badan, antara akal dan nur hidayat, antara ilmu dan agama, antara logika dan cinta, antara rezeki dan ibadah, antara takwa dan tanggung jawab, antara pejabat dan rakyat, antara kulit hitam dan kulit putih, antara yang mulia dan yang jelata, antara kiai dan awam, antara orang timur dan orang barat, antara yang berbahagia dan yang merana, antara yang terang dan gelap, antara orang baik dan orang jahat, antara orang Yunani dan orang Bar-bar, antara Arab dan bukan Arab, antara orang Persia dan bukan orang Persia, antara kapitalis dan proletar, antara elite dan massa, antara yang terpelajar dan yang buta huruf semua bentuk kontradiksi ini hanya ada dalam pandangan hidup syirik dualisme, trinitarianisme dan politeisme, tetapi tidak mungkin ada dalam tauhid, monoteisme." (Ali Syariati, 1982).

Konsep tauhid juga menjadi landasan pola hubungan antara agama dan ilmu pengetahuan. Ali Syariati meyakini bahwa Islam dengan sains tidak memiliki kontradiksi karena dilandasi dengan tauhid. Di antara keduanya tidak ada pemisahan apalagi pertentangan karena sama-sama bersumber dari Allah. Jika Islam bersumber dari wahyu Allah, maka ilmu pengetahuan juga bersumber dari Allah melalui medium ayat-ayat kauniyah. Syariati menanalogikan hubungan antara Allah dengan alam layaknya hubungan antara cahaya dengan pelita. Hakikat alam yang menjadi objek sains adalah cahaya yang memancar dari pelita yang sumbernya adalah Allah (Sari, 2018: 197).

Begitu kontrasnya konsep humanisme Barat dengan Islam menjadi salah satu tantangan integritas identitas minoritas muslim di Barat, khususnya Eropa hari ini. Islam memiliki nilai yang cenderung tidak bergeser secara substansi dari zaman ke zaman. Sebaliknya, filsafat Barat seperti humanisme adalah hasil dari evolusi pemikiran manusia yang kerap berubah meskipun tren utamanya tetap menjauhkan diri dari agama. Penganut humanisme ateistik yakin betul bahwa nilai moralitas bisa disusun beradasarkan kehendak bebas dari publik. Moralitas tidak perlu dirujuk lagi dari ajaran agama karena menurut mereka jika ajaran agama memang untuk manusia maka seharusya manusia yang menjadi tolak ukur.

Dalam catatan Hamid Fahmy Zarkasyi (2012: 54), humanisme hari ini tidak hanya pindah rumah dari agama melainkan sudah menjadi musuh agama. Humanisme juga sudah tidak lagi menyekulerkan agama melainkan menjadikan paham sekuler itu sendiri sebagai agama. Pendapat ini dikeraskan melalui karya-karya intelektual Barat seperti Charles Francis Potter (1930) yang menulis buku dengan judul yang sangat provokatif, "humanism: a new religion". Selanjutnya ketika ortodoksi Kristen mulai lemah di Barat, maka resistensi terkuat menyisakan ajaran Islam dengan komunitas 
minoritas muslim yang justru terus berkembang. Resistensi inilah yang pada tingkat tertentu memunculkan konflik sehingga berujung pada hambatan proses integrase identitas muslim di Barat.

\section{Trauma Perang Salib}

Faktor berikutnya yang merupakan hambatan integrasi identitas komunitas muslim di Barat adalah trauma Perang Salib yang melibatkan dua entitas agama yaitu Islam dan Kristen. Catatan menarik pernah ditulis oleh Muhammad Asad (1981: 57-58) yang mengatakan bahwa ada semacam tendensi yang lebih bersifat emosional tatkala Barat berhadapan dengan Islam. Sebagai contoh menurut Asad, sekalipun Barat menolak klaim ajaran Hindu dan Budha, tetapi mereka mampu bersikap objektif dan reflektif terhadap keduanya. Hal yang kontras ketika mereka berhadapan dengan Islam yang bagi Asad membuat Barat kehilangan daya intelektual dan objektifitas mereka.

Muhammad Asad (1981: 61) menegaskan dalam catatannya bahwa bagi Barat, Perang Salib adalah faktor pertama sekaligus utama yang membentuk cara pandang mereka terhadap Islam. Perang ini juga yang membentuk persatuan absolut di dataran Eropa yang pada masa sebelumya terbelah-belah berdasarkan garis etnis dan ras. Pada masa inilah, atas supervisi gereja, beragam istilah dan pemahaman yang salah mengenai Islam disebarluaskan untuk menyemangati pasukan Salib dalam merebut wilayah yang telah dikuasai Islam. Beragam cerita dikarang dan disebarluaskan untuk membangun citra Islam sebagai agama yang jahat dan biadab. Eropa sendiri saat itu masih sangat tertinggal dibandingkan rivalnya di Timur (dunia Islam). Kemiskinan dan kemelaratan yang melanda benua ini membuat tingkat literasi mereka pun begitu rendah sehingga dengan sangat mudah dimobilisasi untuk ikut berperang. Tidak hanya menjanjikan balasan surga bagi mereka yang ikut berperang, pihak gereja juga menjanjikan kehidupan dunia yang lebih baik melalui penguasaan tanah-tanah yang akan mereka rebut. Motif inilah yang hidup dan menyemangati bangsa Eropa sepanjang Perang Salib.

Dalam perkembangannya, Barat kemudian melepaskan diri dari tradisi keagamaan dalam mengatur tata nilai kehidupan. Era ini sering disebut zaman pencerahan (renasisans) atau kelahiran kembali. Hal yang unik adalah ketika rasa benci terhadap Islam justru tetap ada meskipun tradisi pemikiran di Barat telah banyak berevolusi. Tatkala era renaisans membuka cakrawala rasionalisme dan kemajuan material di Barat, ketidaksukaan terhadap Islam masih tetap eksis. Para intelektual Barat di era modern cenderung sanggup bersimpati dan objektif pada beragam aliran kepercayaan di luar mereka, kecuali Islam. Kondisi ini diperaparah oleh generasi awal para orientalis yang menjelajah ke negeri-negeri Islam yang merupakan para pemuka agama Kristen. Terjadi ketimpangan perspektif dan kekacauan objektifitas ketika mereka membentuk narasi mengenai Islam dan dunia Timur pada umumnya. Kondisi inilah yang dikritik Edward Said (1978) dalam bukunya yang berjudul Orientalisme. Menurut Said, secara sederhana bisa dikatakan bahwa Baratlah yang mendefinisikan apa itu Barat dan apa itu Timur (Islam).

Senada dengan pendapat Muhammad Asad, Samuel P Huntington (2005: 375) menambahkan bahwa persaingan antara Islam dengan Kristen memilik tendensi berbeda dibandingkan dengan persaingan modern antara demokrasi liberal versus Marxisme-Leninisme. Bagi Huntington, konflik antara demokrasi liberal versus Marxisme-Leninisme pada abad 20 hanya fenomena dinamika sejarah yang bersifat sementara dan superfisial. Sedangkan konflik antara Islam dengan Kristen jauh lebih 
dalam dan mengakar pada sejarah perang yang panjang di antara keduanya. Menurut John L Esposito (1992: 46), dinamika sejarah keduanya seringkali tampak sebagai dua komunitas yang saling bersaing dan menatap pada pertempuran yang penuh kematian, demi kekuasaan, tanah, dan jiwa. Lebih jauh, Huntington juga menambahkan bahwa Islam adalah satu-satunya peradaban yang bisa membuat Barat selalu dalam keraguraguan antara hidup dan mati bahkan Islam telah melakukannya sebanyak dua kali. Kali pertama ialah tatkala Islam melalui kekuasaan Turki Utsmani mengepung dan menguasai Konstantinopel pada 1453 dan satu abad setelahnya menguasai Wina pada 1529 (Huntington, 2005: 376).

Termin perang salib kemudian muncul kembali pada 11 September 2001, ketika terjadi serangan teroris pada dua menara WTC di Amerika Serikat. Beberapa saat setelah peristiwa tersebut, Presiden George W Bush sempat menyebutkan termin Perang Salib untuk merangkum situasi yang sedang mereka hadapi. Kisah setelahnya adalah pemahaman global mengenai terorisme internasional yang mengambil bentuk simbolsimbol keislaman. Sekalipun termin perang salib itu jelas salah kaprah, tetapi hal tersebut membuktikan eksisnya trauma perang salib antara Barat yang Kristen dengan dunia Islam. Penggunaan termin tersebut juga sangat efektif untuk menggalang solidaritas di tengah masyarakat Barat untuk sekali lagi menghancurkan dunia Islam secara material dan ideologis.

Kecenderungan Barat untuk kembali mengangkat sentimen konflik antara Islam dan Kristen tampak pada kasus tragedi gereja di Nice, Perancis. Dalam suasana ketegangan antara komunitas muslim dengan pemerintah sekuler di bawah Macron pasca pembunuhan Samuel Paty, terjadi penembakan di gereja yang dilakukan oleh seorang muslim. Komunitas Islam sendiri mengutuk keras tragedi tersebut dan menyatakan bela sungkawa yang dalam pada korban. Meski demikian, otoritas Perancis tetap menggunakan sentimen keagamaan untuk meraih dukungan dari negara-negara Eropa lainnya.

Rangkaian dukungan yang mengutuk aksi penembakan itupun mengalir dari sejumlah pejabat pemerintahan negara-negara Eropa. ${ }^{1}$ Hal ini sekaligus menandakan masih mudahnya sentimen keagamaan yang berakar pada trauma perang salib untuk dihidupkan kembali. Sekalipun masyarakat Barat sudah bertransformasi pada humanisme yang liberal dan ateistik, akan tetapi dalam kasus yang melibatkan komunitas Islam, bias respon itu masih terasa. Dari catatan resmi yang dikumpulkan Aljazeera, hanya Rusia saja yang mengutuk aksi terorisme di Nice itu sekaligus juga mengutuk penistaan terhadap Islam yang terjadi sebelumnya. Artinya, secara objektif pihak Rusia memandang aksi terorisme di Nice adalah bentuk reaksi dari kejahatan sebelumnya. Selebihnya, mayoritas pemimpin negara Barat hanya fokus pada aksi terorisme dan tidak bersimpati pada nilai Islam yang dilecehkan.

\section{Masa Depan Integrasi}

1 https://www.aljazeera.com/news/2020/10/29/how-the-world-reacted-to-deadly-niceattack?fbclid=IwAR3BtQrKFXvNE4FavLOti8nxJiZZHJBqlleevPmPRI5Wa4F2GerVGaHxw24, diakses 29 Oktober 2020. 
Dalam khasanah intelektual Islam era modern, kemajuan peradaban Barat tidak ditempatkan dalam posisi yang diametral dengan Islam. Sebagian intelektual Islam justru tumbuh dengan pemahaman sepenuhnya terhadap kemajuan yang dicapai oleh Barat dalam hal ilmu pengetahuan, sains, dan teknologi. Meski demikian, sebagian besar juga mengonfirmasi adanya permasalahan seputar aspek moral yang bersifat patologis bagi ajaran Islam.

Beberapa intelektual Islam yang berbicara mengenai dialektika peradaban ini adalah Muhammad Abduh, Sayyid Qutb, Hasan Hanafi, Abdurrahman Azzam, dan Muhammad Asad. Namun, di antara sekian banyak intelektual Islam yang melakukan refleksi terhadap dialektika peradaban ini, terdapat tokoh seperti Ziya Gokalp yang justru mengajukan peleburan sepenuhnya peradaban Islam ke dalam peradaban Barat untuk mencapai kemajuan yang menyeluruh.

Dalam pandangan Ziya Gokalp (1968: 22), peradaban adalah jumlah total dari seluruh fenomena sosial meliputi konsep-konsep, ilmu pengetahuan dan sains, termasuk di dalamnya etika, hukum, seni, teknologi, dan sebagainya. Seperti yang dikutip oleh Abdul Jabbar Beg (1986: 15), Ziya Gokalp berpendapat bahwa;

"peradaban suatu bangsa tidak bisa bercampur baur dengan peradaban bangsa lain karena masing-masing mempunyai logika, estetika, dan interpretasi sendiri tentang hidup. Dengan alasan yang sama sebuah peradaban harus diterima sepenuhnya. Kita tidak dapat meminjam hanya bagian-bagian tertentu saja daripadanya; jika kita berbuat demikian kita tidak akan dapat mencerna dan mengasimilasikannya. Sebagaimana agama, peradaban harus diterima secara batiniah, tidak hanya secara lahir saja, karena peradaban persis seperti agama."

Gokalp memang dikenal sebagai seorang pembela sekularisme Ataturk di Turki yang menggeser otoritas Kekhalifahan Islam dengan model Republik modern. Ada kalimat dari Kemal Ataturk yang cukup terkenal terkait proyek sekularisasi di Turki yang intinya adalah bangsa Turki harus meniru dan menduplikasi kemajuan peradaban Barat secara total. Ia menegaskan analogi totalitas meniru peradaban Barat adalah seperti mengambil sekuntum bunga beserta duri-durinya.

Pandangan Ziya Gokalp memunculkan kontroversi di tengah-tengah intelektual muslim lainnya karena menganggap agama di bawah subordinasi konsep nasionalisme. Meski demikian, Gokalp memang hidup dan menandai perubahan zaman secara global di dunia ketika nasionalisme menjadi tren perlawanan terhadap kolonialisme Barat yang melanda dunia Islam. Bedanya, corak sekular di Turki, tempat Gokalp berasal begitu kental sementara di dunia Islam pada umumnya nasionalisme bergerak dengan corak kombinasi sekular-religius.

Masa selanjutnya adalah rangkaian dinamika hubungan zaman baru antara Barat dan Islam pascakolonial dan pascakhilafah. Pada periode inilah proses integrasi identitas muslim di Barat berlangsung dengan sangat dinamis. Kebangkrutan ekonomi dan konflik internal di negara-negara muslim mendorong arus migrasi dan perpindahan penduduk mereka ke wilayah-wilayah Barat yang dianggap lebih menjamin masa depan mereka. Sementara itu, benturan nilai dan keyakinan antara pendatang muslim dan bangsa Barat seringkali tidak dapat dihindari. Pada kasus Perancis, intensitasnya begitu kuat dan memunculkan keresahan yang mendunia. Sekalipun demikian, harapan terhadap integrasi identitas yang damai itu selalu tetap hidup dan diusahakan. 
Seorang Rabi Agung Perancis, Joseph Sitruk memberi komentar melalui The Associated Press mengenai kontroversi karikatur Nabi Muhammad (Esposito dan Mogahed, 2008: 182),

“Tidak ada yang kita peroleh dari meremehkan agama, menghinanya, dan membuat karikatur tentang tokoh-tokoh agama. Hal itu menandakan tidak adanya ketulusan dan respek."

Dalam catatan Esposito dan Mogahed (2008: 200), pola perbaikan hubungan antara masyarakat Barat dan umat Islam tidak didasarkan pada tuntutan perubahan norma sosial dan budaya yang bertentangan, melainkan sekadar penghargaan yang lebih pada keyakinan umat Islam. Dalam penelitian Esposito dan Mogahed, hal yang paling dibenci oleh umat Islam dari Barat adalah tata nilai dan moralitas yang begitu bertentangan dengan ajaran Islam. Meski demikian umat Islam yang hidup di Barat tidak menuntut perubahan moralitas itu untuk disesuaikan dengan ajaran Islam. Tuntutan yang lebih luas diserukan oleh umat Islam justru seputar kebijakan, yaitu:

1. Negara-negara Barat mengambil kebijakan praktis untuk membantu perkembangan ekonomi negara-negara muslim.

2. Negara-negara Barat menahan diri dan tidak ikut campur dengan urusan dalam negeri negara-negara Muslim serta tidak memaksakan keyakinan dan kebijakan.

3. Negara-negara Barat bersikap adil terhadap Palestina, terutama di kalangan negaranegara Arab.

Masa depan integrasi juga bisa dilihat dari kecenderungan masyarakat Barat yang dalam pandangan Chandra Muzaffar (2003: 250-251) saat ini justru sedang masuk dalam tren pencarian spiritualitas. Kesenjangan yang tercipta akibat telah lamanya agama ditinggalkan di Barat memunculkan tren pencarian spiritualitas yang baru di tengah masyarakat Barat modern yang gamang. Muzaffar menyebut fenomena ini sebagai kebangkitan religiusitas di Barat. Di sisi lain, para pemeluk Islam semakin mengonsolidasi ajaran dan kepentingan mempertahankan ajaran di tingkat global. Selain itu, terdapat fenomena konversi keagamaan yang cukup signifikan di Barat untuk memeluk agama Islam. Kombinasi ketiga hal ini, kebangkitan religiusitas Barat, konsolidasi umat Islam, dan konversi agama menjadi peluang emas terciptanya harmoni integritas muslim di Barat.

\section{SIMPULAN}

Krisis integrasi identitas yang dialami oleh komunitas muslim di Barat bisa dirunut pada perbedaan konseptual pada tataran filsafat humanisme dan trauma sejarah perang Salib. Pada tataran humanisme, Ali Syariati berpadangan bahwa masyarakat Barat mewarisi tradisi permusuhan antara manusia dan Tuhan (dewa) di era mitologi Yunani di dalam benak mereka. Meskipun ajaran keagamaan mengalami banyak perubahan di Barat, spirit memusuhi otoritas ketuhanan ini tetap ada di dalam sanubari mereka. Ketika di abad pertengahan gereja Katolik melakukan banyak penindasan terhadap kemanusiaan, semangat untuk melakukan perlawanan ini menggeliat kembali. Pada gilirannya trauma sejarah tersebut melahirkan filsafat 
humanisme yang semangat besarnya adalah menyingkirkan agama dari kehidupan manusia.

Hal berikutnya yang menjadi faktor penghambat proses integrasi muslim di Barat adalah trauma Perang Salib. Ada semacam tendensi yang lebih emosional tatkala masyarakat Barat berhadapan dengan komunitas muslim. Masyarakat Kristen Barat memiliki kecurigaan yang jauh lebih besar ketika berhadapan dengan komunitas muslim daripada dengan komunitas agama lainnya. Hal ini semakin diperparah dengan fenomena terorisme internasional yang seringkali membawa secara harfiah simbolsimbol keislaman dan sekaligus kebencian terhadap Barat.

Kesadaran penuh terhadap perbedaan konsep filsafat humanisme dan trauma sejarah Perang Salib diharapkan bisa menyadarkan seluruh eksponen masyarakat Barat untuk mendukung proses integrasi umat Islam. Di sisi lain, umat Islam harus terus menempa diri untuk memajukan sains dan teknologi dalam kerangka keimanan yang inklusif. Umat Islam juga harus menahan diri pada gesekan-gesekan nilai yang tidak terelakkan dengan masyarakat sekuler Barat sehingga tidak terjebak pada aksi reaksioner yang kontra produktif pada proses integrasi secara keseluruhan.

\section{Daftar Pustaka}

Mujiburrahman. (2018). Indonesian Translation and Appropriation of the Works of Shariati and Hanafi in the New Order's Islamic Discourses, Studia Islamika. Vol.25 No.2.

Syari’ati, Ali. (1996). Kritik Islam atas Marxisme dan Sesat-Pikir Barat Lainnya. Bandung: Mizan.

Ummah, Siti Syamsiatul. (2019). Teologi Pembebasan Ali Syari'ati (Kajian Humanisme dalam Islam). 'Ainil Islam: Jurnal Kebudayaan dan Ilmu Keislaman. Vol.12 No.1. Yogyakarta: UIN Sunan Kalijaga.

Asad, Muhammad. (1981). Islam di Simpang Jalan. Bandung: Pustaka.

Beg, Muhammad Abdul Jabbar. (1986). Perspektif Peradaban. Bandung: Pustaka.

Pals, Daniel L. (2018). Seven Theories of Religion: Tujuh Teori Agama Paling Berpengaruh. Yogyakarta: IRCiSoD.

Lebor, Adam. (1998). A Heart Turned East: Among The Muslims of Europe and America. New York: St. Martin`s Press.

Muzaffar, Chandra. (2004). Muslim, Dialog dan Teror. Jakarta: Profetik.

Harari, Yuval Noah. (2018). 21 Lessons: 21 Adab untuk Abad 21. Manado: Global Indo Kreatif.

Gokalp, Ziya. (1968). The Principles of Turkism. Leiden: Brill Archive 
Zarkasyi, Hamid Fahmy. (2012). Misykat: Refleksi Tentang Westernisasi, Liberalisme, dan Islam. Jakarta: INSISTS-MIUMI.

Huntington, Samuel P. (2005). Benturan Antar Peradaban dan Masa Depan Politik Dunia. Yogyakarta: Qalam.

Esposito, John L. (1992). The Islamic Threat: Myth or Reality. New York: Oxford University Press.

Esposito, John L dan Dalia Mogahed. (2008). Saatnya Muslim Bicara!: Opini Umat Muslim tentang Islam, Barat, Kekerasan, HAM, dan Isu-Isu Kontemporer Lainnya. Bandung: Mizan.

Sari, Zamah. (2018). "Relevansi pemikiran Sosiologi Islam Ali Syariati dengan problematika Pendidikan Islam di Indonesia". Ta`dibuna Jurnal Pendidikan Islam Vol.7 No.2 Oktober 2018. http://ejournal.uikabogor.ac.id/index.php/TADIBUNA/article/view/1354, diakses 20 Desember 2020.

Cahyanto, Fitri. (2020). "Filsafat Manusia Ali Syariati: Kesadaran dan Kebebasan Manusia di Era Revolusi Teknologi 4.0". Academic Journal of Islamic Prinsiples and Philosophy Vol.1 No.1 2020. http:/ / ejournal.iainsurakarta.ac.id/index.php/ajipp/article/view/2413, diakses 20 Desember 2020. 